\title{
Analysis Of The Effect Telephone Counseling By Nurses On The Compliance Of The Control Of Dots Poly Tuberculosis Patients At Dungus Madiun Lung Hospital
}

\author{
Agus Winarto ${ }^{1}$, Tjahja Bintoro ${ }^{2}$ \\ ${ }^{1}$ RS Paru Dungus, Madiun, East Java, Indonesia \\ ${ }^{2}$ PPNI Madiun, East Java, Indonesia) \\ Corresponding author : aguswinarto2015@gmail.com
}

\begin{abstract}
Background: Adherence to treatment is the behavior of TB patients to come control in accordance with control schedule in DOTS Poly Dungus Madiun Lung Hospital. Telephone counseling is a communication performed by nurse DOTS Poly Dungus Madiun Lung Hospital to the TB patient or his family using a telephone, with the intention of asking about the state of his illness, current complaints, motivate regularly taking medication, answer patient questions and complaints, and reminded drug taking schedule.

Purpose : The purpose of this study is to prove the influence of the provision of telephone counseling by nurses to the compliance of TB DOTS patient control in Dungus Madiun Lung Hospital.

Methods : Research design Pre- Experiment with a one-shot case study design. The population is TB Patients treated in poly DOTS from January 2017 to March 2017 with a sample of 15 respondents by purposive sampling. Data collection using a checklist of telephone counseling and checklist the observation of the arrival of the control on time after given counseling via telephone,checklist data was analyzed with Binomial Test.

Result : Research result, after counseling via telephone almost all respondents came to the control on time 13 respondents $(87 \%)$ and there is the effect of telephone counseling by nurses on the compliance of the control of DOTS poly tuberculosis patients at Dungus Madiun Lung Hospital. (Binomial with sig $=0.007<\alpha=0.05$ then $\mathrm{H} 0$ is rejected).

Conclusion : Provision of counseling is necessary to improve patient compliance in treatment until completion. With telephone counseling from TB DOTS poly nurse to patient, in addition to more effective communication awakening, as well as motivating patients to adhere to TB treatment programs.
\end{abstract}

Keywords : Telephone counseling, Compliance Control, TBC patients

Received: February 03, 2018; Revised February 24, 2018; Accepted March 10, 2018

How to Cite: Winarto, A., \& Bintoro, T. (2018). Analysis Of The Effect Telephone Counseling By Nurses On The Compliance Of The Control Of Dots Poly Tuberculosis Patients At Dungus Madiun Lung Hospital. Journal Of Nursing Practice. 1(2). 47-52 


\section{BACKGROUND}

Tuberculosis is a disease of global concern. With all the control measures undertaken, incidences and deaths from Tuberculosis have declined, but Tuberculosis is estimated to still strike 9.6 million people and cause 1.2 million deaths by 2014 .

By 2015 the national treatment success rate is $85.0 \%$ (data as of June 2016). WHO set the standard of treatment success rate of $85 \%$. From East Java Provincial Health Office data obtained data that the discovery and cohort analysis on the treatment data conducted in 2011 showed that the success rate of the provincial scale is good enough. If the treatment outcome is sorted according to fashankes, then the results are as follows: Puskesmas is still the fasyankes with the best treatment success rate of $91 \%$, private practice doctor $88 \%$, general hospital $71 \%$, lung hospitals and BP4 63\%.

Treatment drop out rates as a result of medication noncompliance is one of the important indicators of treatment performance and affect the quality of treatment. The higher the drop out rate in a region / fasyankes, there is a tendency to increase the rate of finding new cases or even increasing cases of MDR in the region. Public hospitals, lung hospitals / BP4 are fasyankes who have a risk for high drug drop out rate with a medication drop out rate of $19 \%$ when compared with puskesnas with $2 \%$ dropout rate. Dropout rates at Dungus Madiun Hospital 2016 by 10\% while the maximum number of patients with treatment drop by $5 \%$.

TB patients in DOTS Dungus Madiun Hospital were found that there were 862 patients from January to December 2016, there were 86 treatment drop out rate $(9.98 \%)$, mostly at the advanced treatment stage between month the 5th to the 6th treatment was $95 \%$, and $5 \%$ of the treatment drops occurred during the initial treatment period, precisely at month 2. $=$, but after fieldwork that out of the 86 patients recorded in the dorp out patient, after the search was found 30 patients moved to residence without notice, 7 patients died, and 49 stopped treatment. This shows the lack of communication caused the difference in the data information recorded.

\section{OBJECTIVE}

The purpose of this study is to prove the influence of the provision of telephone counseling by nurses to the compliance of TB DOTS patient control in Dungus Madiun Lung Hospital.

\section{METHODS}

This research is a quantitative research, with research design using Pre-Experiment method, and the research design used is one-shot case design study with randomized sample, used to see the effect of treatment (counseling via telephone) to the compliance of poly DOTS TB patient control Dungus Madiun Lung Hospital.

The population is TB Patients treated in DOTS poly from January 2017 to March 2017. Samples are TB Patients who are in the control category of irregular / non-compliance control scheduled control in May 2017, with sampling purposive sampling technique, 15 respondents.

Independent Variable in the form of giving counseling via telephone by DOTS policeman. And the dependent variable is the compliance of the control of poly tuberculosis patient DOTS at Dungus Madiun Lung Hospital.

Samples were obtained in DOTS poly according to schedule control list in accordance with inclusion and exclusion criteria. Next we concerned the sample as a prospective respondent and included in the table of prospective respondents. And when the respondent 
comes for treatment and meets first with the researcher, the researcher explains the purpose and objectives of the research on the respondent and gives informed consent to the respondent to be signed when approve. Explain to the responder that between $\mathrm{H}-7$ and H-2 of the next control schedule will receive a call from the researcher. If telephone counseling has been done by the researcher to the respondent, then the researcher will give the sign $(\sqrt{ })$ in the counseling check box via telephone. Furthermore, when the schedule of subsequent control respondents, researchers make observations and attendance attendance attendance control. If the respondent comes timely control on schedule or before, then the compliance observation checklist is marked 1 in the compliance control column. If the respondent does not arrive on the day as scheduled or arrives late from schedule, then the number 0 is in the compliance control column.

Data from counseling check list via telephone and checklist of observation control, then data characteristic of respondent shown in pie and narration diagram. To know the effect of giving counseling via telephone to compliance of control carried out statistical test non parametric Binomial.

\section{RESULTS}

The respondents in this study were some of the TB patients who were recorded in the non-compliant control or irregular control scheduled controls in May 2017, as many as 15 respondents.

Characteristics of respondents are declared by domicile, sex, age, result of BTA examination, and treatment stage, as follows the following:

1. Most of the respondents came from Madiun Regency with 10 people or $67 \%$.

2. Most of the respondents are male with the number of 9 people or $60 \%$.

3. Almost half of respondents are aged 61 years and over with the number of 6 people or $40 \%$.

4. Most of the respondents were patients with TB of BTA Negatif with number of 11 people or $73 \%$.

5. Almost all respondents in the treatment period continued with the number of 13 people or $87 \%$.

Characteristics of the variable as follows:

1. Independent variable in the form of giving telephone counseling by nurses was done to all respondents who experienced control delay that is 15 respondents.

2. Dependent variables in the form of compliance control, after giving counseling via telephone, indicate that almost all respondents obedient control on time, with the number of 13 people or $87 \%$.

Table 1. Binomial statistic test results using SPPS as follows

Binomial Test

\begin{tabular}{rlrrrr}
\hline & Category & N & Observed Prop. & Test Prop. & Exact Sig. (2-tailed) \\
\hline Group 1 & compliant & 13 & .87 & .50 & .007 \\
Kepatuhan Group 2 & non-compliant & 2 & .13 & & \\
Total & & 15 & 1.00 & & \\
\hline
\end{tabular}


From the output obtained that the Category is obedient $=13$ and the Uncompliance Category $=2$, Proportion 1.0, Exact Value sig $=0.007$, Level of significance $\alpha=0.05$ Value sig $=0.007<\alpha=0.05$

Conclusion: Since the value of $\operatorname{sig}=0.007<\alpha=0.05$ then H0 is rejected which means that there is the effect of giving telephone counseling on patient control compliance in DOTS RS Dungus Madiun.

\section{DISCUSSION}

Identification of TB DOTS patient's control compliance after being counseled via telephone by nurse at Dungus Madiun Dung Hospital.

The results showed that after giving counseling via telephone, almost all patients who had been late to control to be obedient control on time, with the number of 13 respondents or $87 \%$. There are still a small number of patients who have not adhered to timely control, ie as many as 2 respondents or $13 \%$.

When connected with the respondent characteristic data obtained identification of control compliance observation result after given counseling via phone on $\mathrm{H}-7$ to $\mathrm{H}-2$ from schedule control it is as follows:

1. Based on the respondent's domicile (Regency), the respondents obtained from Ponorogo, Magetan, Nganjuk 100\% obedient after given counseling via telephone, while respondents from Madiun Regency as many as $8(80 \%)$ respondents obedient and $2(20 \%)$ respondents did not obey.

2. Based on respondent's gender, male respondent 7 (100\%) respondents submitted after giving counseling via telephone, while female respondents were 6 respondents $(75 \%)$ obedient and 2 respondents $(25 \%)$ did not obey.

3. Based on the age group of respondents, obtained respondents age group 1-20 years, 2140 years and 61 years and over 100\% obedient respondents abide after given counseling via telephone. While respondents age group 41-60 years as many as 2 respondents $(50 \%)$ obedient and as much as 2 respondents $(50 \%)$ are not obedient.

4. Based on the results of BTA examination of respondents, obtained respondents with the results of BTA Negative examination of 11 people, $91 \%$ obedient and $9 \%$ not obedient. While respondents with positive BTA examination results as many as 4 people, $75 \%$ obedient and $25 \%$ disobeyed after being given counseling via telephone.

5. Based on the treatment period of the respondents, the respondents obtained the intensive treatment period as much as 2 respondents, $50 \%$ obedient and $50 \%$ tidal obedient. While respondents with treatment period continued as many as 13 respondents, $92 \%$ obedient and $8 \%$ disobedient.

Analysis of the effect of telephone counseling by nurses on the compliance of the control of DOTS poly tuberculosis patients at Dungus Madiun Dung Hospital

The results showed that there was influence of telephone counseling on patient compliance control. This is evidenced by the results of binomial analysis performed with SPSS, which states the value of Exact sig $=0.007$ smaller than the level of significance $\alpha=0.05$.

The results also showed that after counseling via telephone, there was an increase in the percentage of control compliance rates when compared with control compliance rates before being given counseling via telephone. The compliance rate before counseling via telephone was 39 compared to $54=72 \%$, whereas the rate of compliance after counseling via telephone was 13 compared to $15=82 \%$. 
Counseling is a process of giving help done by an expert (called counselor / counselor) to an individual experiencing a problem (called counselee) which leads to the problem faced by the client. Counseling is one form of communication that has a purpose to change the current situation to a better state. Prayitno (2004). The researcher's opinion, in the group of respondents who are a group of TB sufferers who need a long period of time, at least 6 months for the duration of treatment, it is necessary to get counseling in addition to increase the motivation of undergoing treatment, also provide solution solutions when there are obstacles during the treatment.

Advantages or advantages of counseling counseling services over the phone, among others in addition to the client more willing to open talk about the problem because he does not communicate face to face, so he can be more ready and open, can also reduce the difficulty of the schedule of activities and distance (Wikipedia.org). The idea of using telephone media to provide counseling from researchers is a new step in the continuation of counseling that has been routinely given when patients come for treatment and meet both physicians and nurses in poly DOTS, on the grounds that there are still high levels of control delay also because each each individual already has a telephone tool.

In a study conducted by I Made Bagiada and Ni Luh Putri Primasari in 2010 on factors that influence the degree of non-compliance of Tuberculosis patients in the DOTS clinic at Sanglah Denpasar Hospital, it is found that one of the factors is the patient's own problem, such as the lack of knowledge about TB, lack of costs, lazy treatment, and feel healed. From the results of I Made Bagiada research, researchers can conclude that many factors that can affect the non-compliance of Tuberculosis patients to be able to seek treatment regularly and on time and complete in term. The treatment program of Tuberculosis patients takes a relatively long time between 6 months to 9 months. To minimize the factors that affect the non-adherence of tuberculosis patients, researchers try to provide a treatment to monitor and increase motivation in patients and their families in the form of counseling via telephone. In the counseling will be obtained information on the current condition of the patient, the complaints experienced, the obstacles experienced so that patients do not take their own decisions that can harm. Researchers can provide solutions to the problems that are being experienced by patients and can remind the next control schedule.

The degree of patient disobedience can be influenced by the communication between patient and physician, for example, information with poor supervision, dissatisfaction with aspects of emotional connection with physicians, dissatisfaction with treatment (Given, 2004). Telephone counseling is a treatment to improve the quality of communication from health workers with patients. Improving the quality of communication is expected to increase compliance rates. Increasing compliance rate of respondent control after counseling via telephone shows that by improving communication between patient and health officer will influence patient's disobedience level,

From the medical journal made by Rina Loriana, Ridwan M.Thaha, Iwan M. Ramdan Mulawarman University of Samarinda (2012) stated that "That there is a significant difference of knowledge about the adherence of patients receiving pulmonary TB treatment before and after getting counseling, there is a significant difference in attitude about the treatment of patients with TB Lung before and after getting counseling and there are significant differences in the level of treatment compliance in patients with pulmonary TB before and after getting counseling. It can be concluded that the effect of counseling on knowledge, attitudes and compliance to treatment of Pulmonary TB patients in the working area of the Health Service of Samarinda City. 


\section{CONCLUSION}

After the research can be concluded that After being given telephone counseling by the nurse, almost all TB poly DOTS patients who have been late to control become obedient control on time. The influence of giving counseling via telephone to the compliance of treatment of pulmonary tuberculosis patients in Poli DOTS Lung Hospital Dungus Madiun.Pengaruh giving counseling via telephone to TB patients who once late control in particular, in addition to improve the quality of communication can also motivate TB patients in the program treatment.

\section{REFERENCES}

Ariesubowo, (2008). “Komunikasi-Dengan-Pelanggan" ( https://wordpress.com). Diakses tanggal 20 Januari 2017

Dinkes Kab. Madiun. (2013). Profil Kabupaten Madiun. (http://www.depkes.go.id/resources/download/profil/PROFIL_KAB_KOTA_2013/ 3519_Jatim_Kab_Madiun_2013.pdf). Diakses tanggal 20 Januari 2017.

Dinkes Kab. Madiun. (2015). Profil Kabupaten JawaTimur. (http://dinkes.jatimprov.go.id/userfile/dokumen/PROFIL\%20KES_2015.pdf). Diakses tanggal 20 Januari 2017.

Mulyana, Deddy. (2010). Ilmu Komunikasi. Bandung: Remaja Rosdakarya.

Niven, Neil. 2004. Psikologi Kesehatan Keperawatan Pengantar untuk Perawat dan Profesional Kesehatan lain. Jakarta: EGC.

RI, Depkes. (2007). Pedoman Pengelolaan Program TB Nasional, Jakarta: Depkes

RI, Depkes. (2011). Pedoman Pengelolaan Program TB Nasional, Jakarta: Depkes

RI, Depkes. (2014). Pedoman Pengelolaan Program TB Nasional, Jakarta: Depkes

Siswanto, Susilo, dan Suyanto, (2015). Methodologi Penelitian Kesehatan dan Kedokteran. Jogjakarta : Bursa Ilmu

Soepritjahjono,(2013).“Pengertian-Komunikasi-Teleponl”https://wordpress.com). Diakses tanggal 20 Januari 2017.

Sugiono. (2003). Methodologi Penelitian Admistrasi. Bandung: CV Alfabeta

Wiki, (https://id.wikipedia.org/wiki/Telepon). Di akses tanggal 19 Maret 2017.

Wiki, (https://id.wikipedia.org/wiki/Konseling). Diakses tanggal 19 Maret 2017 